\title{
Ayurvedic management of Vatakantaka (Plantar Fasciitis)
}

\author{
Research Article
}

Veena.G.Rao $^{1^{*}}$, Nischitha.MS ${ }^{2}$

1. Asst.professor, Dept.of Panchakarma, 2. Lecturer, Dept. of Rasashastra, JSS Ayurveda Medical college, Lalithadripura road, Mysore 28.

\begin{abstract}
Background: Vatakantaka/plantar fasciitis is a common cause of heel pain with peak incidence between 40 to 60 yrs of age. Though NSAID's pain will be relieved temporarily, hence promising curative treatment for the condition is highly essential.

Objectives: To Evaluate the Efficacy of Eranda Taila Nitya Virechana and Sthanika Kolakulathadi Upanaha In Vatakantaka/Plantar fasciitis .

Methods: 20 patients with confirmed clinical diagnosis of vatakantaka/plantar fasciitis were administered Eranda taila nitya virechana and kolakulathadi upanaha over affected heels for 15 days.

Results: From the statistical analysis of the recorded data it is evident that in $70 \%$ of patients heel pain \& swelling relieved completely within 15 days of treatment. So, this treatment can be effectively adopted in patients of vatakantaka.
\end{abstract}

Keywords: Eranda taila, vatakantaka, plantar fasciitis, kolakulathadi upanaha.

\section{Introduction}

Plantar fasciitis is a common cause of heel pain in adults with the peak incidence occurring in people between the ages of $40-60 y$ rs as stated by Harrison. $70 \%$ of patients presents with unilateral heel pain.

It is seen more frequently in a younger population consisting of runners, aerobic exercise dancers and ballet dancers.

Vatakantaka is painful disorder of ankle joint. Aggravated vata, because of exertion(1) \& walking on uneven surface takes ashraya in gulfa sandhi and

\footnotetext{
*Corresponding Author:

Veena.G.Rao

Asst.professor, Dept.of Panchakarma,

JSS Ayurveda Medical college,

Lalithadripura road, Mysore 28.

Mob: +919844549152,

E mail:drveenagrao@yahoo.in
}

produces pain(2). As the pain is seen more during morning and after a period of inactivity in patients, it indicates the samsarga of kapha or presence of ama with the vata. Here production of ama is expected from the avarana of koshtagni by aggravated vata as explained by charaka in nidanashana(3). Here dushyas are snayu \& sandhi and rogamarga is madhyama.

With this pathology and clinical presentation vatakantaka can be effectively paralleled with plantar fasciitis. Pathology reveals chronic inflammation of plantar fascia and degeneration of fibrous tissue with or without fibroblast proliferation.

Several factors that increase the risk of developing plantar fasciitis include obesity, pes planus (excessive pronation of the foot), pes cavus (high arched foot), and limited dorsiflexion of the ankle, walking on hard surface and faulty shoes. In runners, excessive running and a change to 
a harder running surface may precipitate plantar fasciitis.

Patients presents with severe pain at plantar region of heel. Pain will be severe with the first steps on rising in the morning or following inactivity during the day. It also worsens with continued weight bearing activity, on walking barefoot or upstairs. Medical arch support, foot strapping, or taping, night splint is employed as a part of treatment. Short course of NSAID's provide temporary relief from pain. Local glucocorticoid injections though efficacious, may carry an increased risk for plantar fascia rupture. Plantar fasciotomy surgery is reserved for chronic sufferers (4).

With the intention to provide a better promising treatment for the absolute relief of pain through Ayurveda, this study is undertaken.

Diagnosis of plantar fasciitis is purely clinical. However imaging studies may be indicated when the diagnosis is not clear(5).

Plain radiograph may show heel spur in $50 \%$ of cases. Bone scan demonstrates increased uptake at the attachment of the planter fascia to the calcaneus.

USG demonstrates thickening of fascia and diffuse hypo echogenicity. MRI is sensitive but not required for establishing the diagnosis.

Classical line of treatment for vatakantaka:

Raktavasechanam kuryat abheekshnam Vatakantake I

Pibederandatailam va dahet soochibhireva cha II(6)

(Bhi.Rat.26/48)

Snehopanaha agnikarma bandhana unmardanani cha I

Snayu sandhyasti samprapte kuryat vayaavatandritaha II (7)

(Su. Chi. 4/8)

Local snehana, upanahaa, agnikarma, raktamokshana, bandhana, unmardana and oral administration of eranda taila are the classical line of treatment for vatakantaka.

\section{Aims and objectives:}

To evaluate the efficacy of eranda taila nityavirechana and sthanika kolakulathadi upanaha in vatakantaka w.s.r. to plantar fasciitis.

\section{Materials and methods:}

20 patients with confirmed clinical diagnosis of vatakantaka/plantar fasciitis were taken for the study.

\section{Inclusion criteria:}

a) Patients with pratyatma lakshanas of vatakantaka i.e, pain in the plantar aspect of heel, pain on keeping the first step in the morning with or without local swelling, stiffness and tenderness.

b) Irrespective of sex.

c) Age group between 20-60yrs.

\section{Exclusion criteria:}

a) Calcaneal stress fracture, RA, gout, neoplastic condition, nerve entrapment syndromes.

b) Subjects with impaired circulation to lower extremities.

c) Subjects with referred pain due to sciatica \& other neurological disorders.

d) Corticosteroid injections to heel, preceding 3 months.

Investigation: X-ray of affected heel.

Diagnostic criteria: Purely clinical. Based on

a) Heel pain \& stiffness as subjective parameter

b) Heel tenderness \& swelling as objective parameter.

Materials \& methods:

Materials taken for the study are

a) Eranda taila 
b) Shunti kashaya (5g of shunti churna added with $80 \mathrm{ml}$ of water, boiled and reduced to $20 \mathrm{ml}$ and filtered) (7).

c). Kolakulathadi churna (8):
Ingredients are fine powders of Atasi beeja, Kushta, Shatapushpa, Vacha, Yava, Kola, Kulatha, Devadaru, Rasna, Masha in equal quantity. Rationality behind selection of these drugs for the study is explained under discussion.

Table 1: Showing ingrediants \& their actions of kolakulathadi churna

\begin{tabular}{|l|l|l|l|l|}
\hline $\begin{array}{l}\text { Sl. } \\
\text { No }\end{array}$ & Drug name & Latin name & Parts used & Action \\
\hline 1 & Kola & Zizyphus jujuba Lam. & Beeja & Kapha Pittahara \\
\hline 2 & Kulattha & $\begin{array}{l}\text { Macrotyloma uniflorum } \\
\text { Linn. }\end{array}$ & Seeds & Shothahara vatahara \\
\hline 3 & Devadaru & Cedrusdeodara Loud. & Khadha & $\begin{array}{l}\text { Vedana } \\
\text { Sthapana }\end{array}$ \\
\hline 4 & Rasna & $\begin{array}{l}\text { Pluchea } \\
\text { C.B.Clarke. }\end{array}$ & Phothahara Vedanashamaka \\
\hline 5 & Maasha & Phaseolus Mungo Linn. & Peeja & $\begin{array}{l}\text { Vedanashamaka } \\
\text { Vatashamaka }\end{array}$ \\
\hline 6 & Atasi & Linun usitatissimum Linn. & Beeja & Vatashamaka shothahara \\
\hline 7 & Kusta & Saussurea lappa C.B.Clarke. & Moola & $\begin{array}{l}\text { Vedanashamaka } \\
\text { vatashamaka }\end{array}$ \\
\hline 8 & Shatapushpa & Anathum sowa Kurz. & Beeja & Vedanashamaka \\
\hline 9 & Vacha & Acorus calamus Linn. & Mula & Vedanashamaka shothahara \\
\hline 10 & Yava & Hordeum vulgare Linn. & $\begin{array}{l}\text { Fruit, } \\
\text { whole } \\
\text { plant }\end{array}$ & $\begin{array}{l}\text { Kaphavata } \\
\text { Shamaka }\end{array}$ \\
\hline
\end{tabular}

\section{Study design:}

All selected patients were given Eranda taila $10-30 \mathrm{ml}$ with $20 \mathrm{ml}$ of shunti kashaya orally at 8.00 a.m. in empty stomach depending on the koshta expecting not more than 3-4 virechana vegas. Patients were advised to avoid sweets, fried food, peas, potato, curds during the treatment.

A paste is prepared by adding required quantity of water to 15 to $20 \mathrm{~g}$ of kolakulatthadi churna. In the morning, it is applied warm to the affected heel, covered with eranda leaves, tied with a thin cloth(10) and advised to retain for $4 \mathrm{hrs}$. As drugs of kolakulatthadi churna are ushna \& teekshna (leads to local skin irritation), this upanaha is advised to retain only for 4 hrs, though there is classical reference of upanahas keeping for 12hrs(11).
Chakrapani opines that the lepa should be thick in upanaha(12) but he has not mentioned the exact thickness. Here the thickness of $5 \mathrm{~mm}$ is maintained, so that it should not be thin.This Eranda taila nityavirechana and sthanika Kolakulathadi upanaha were carried out continuously for 15 days.

\section{Assessment criteria:}

Signs and symptoms were scored 0,1,2,3.
a) Heel pain:
No pain -0
Mild discomfort -1
Distressing pain -2
Severe excruciating pain -3
b) Local tenderness:
No tenderness -0
Mild tenderness - 1
Moderate tenderness -2 
Severe tenderness -3

c) Local swelling:

No swelling - 0

Mild swelling - 1

Moderate swelling - 2

Profuse swelling -3

d) Local stiffness:

No stiffness -0

Mild stiffness -1

Moderate stiffness - 2

Severe stiffness -3

Data's regarding above said features were collected on $1^{\text {st }} 7^{\text {th }}$ and $15^{\text {th }}$ day. Two follow-ups were done on $30^{\text {th }}$ and $45^{\text {th }}$ day after commencement of treatment. These data was subjected to statistical analysis by applying students unpaired t test. $\mathrm{P}$ value was calculated by referring to Fischer's table at corresponding level of degree of freedom.

\section{Overall assessment:}

1. Major improvement:- reduction in more than $80 \%$ of initial score after treatment

2. Moderate improvement: - reduction in more than $50 \%$ to $80 \%$ of initial score after treatment

\section{Results:}

Table 2: Showing the statistical analysis of mean clinical feature score before $\&$ after 7 days of treatment

\begin{tabular}{|l|l|l|l|l|l|l|}
\hline $\begin{array}{l}\text { Clinical } \\
\text { features }\end{array}$ & $\begin{array}{l}\text { B.T } \\
\text { +/-SD }\end{array}$ & $\begin{array}{l}\text { A.T } \\
\text { +/-SD }\end{array}$ & $\begin{array}{l}\text { S.Eof } \\
\text { difference }\end{array}$ & $\begin{array}{l}\text { Mean } \\
\text { difference }\end{array}$ & Tvalue & Pvalue \\
\hline pain & $2.15+/-$ & $\begin{array}{l}1.20+/- \\
0.70\end{array}$ & 0.050 & 0.95 & 19.00 & $<0.0001$ \\
& 0.75 & 0.70 & & & \\
\hline swelling & $0.75+/-$ & $0.25+/-$ & 0.227 & 0.50 & 2.2072 & $<0.0334$ \\
& 0.85 & 0.55 & & & & \\
\hline stiffness & $1.75+/-$ & $0.55+/-$ & 0.222 & 1.20 & 5.4094 & $<0.0001$ \\
& 0.72 & 0.69 & & & & \\
\hline tenderness & $2.10+/-$ & $\begin{array}{l}1.00+/- \\
0.79\end{array}$ & 0.240 & 1.10 & 4.5926 & $<0.0001$ \\
& 0.72 & & & & \\
\hline
\end{tabular}

Table 3: Showing the statistical analysis of mean clinical feature score before $\&$ after 15 days of treatment

\begin{tabular}{|l|l|l|l|l|l|l|}
\hline $\begin{array}{l}\text { Clinical } \\
\text { features }\end{array}$ & $\begin{array}{l}\text { B.T } \\
\text { M+/-SD }\end{array}$ & $\begin{array}{l}\text { A.T } \\
\text { M+/-SD }\end{array}$ & $\begin{array}{l}\text { S.Eof } \\
\text { difference }\end{array}$ & $\begin{array}{l}\text { Mean } \\
\text { difference }\end{array}$ & T value & Pvalue \\
\hline Pain & $2.15+/-$ & $0.35+/-$ & 0.199 & 1.80 & 9.0298 & $<0.0001$ \\
& 0.75 & 0.49 & & & & \\
\hline swelling & $0.75+/-$ & $0.00+/-$ & 0.190 & 0.75 & 3.9428 & $<0.0003$ \\
\hline
\end{tabular}

3. Minor improvement:- reduction in more than $25 \%$ to $50 \%$ of initial score after treatment.

4. No improvement: - reduction less than $25 \%$ of initial score treatment.

\section{Observations:-}

It is observed that in the random selection of 20 patients $40 \%$ were housewives, $40 \%$ were businessmen, $20 \%$ were having sedentary life style. $20 \%$ were males \& $80 \%$ were females. $60 \%$ were non-vegetarians \& $40 \%$ vegetarians. $10 \%$ with 10-12 months of chronicity, $20 \%$ with 6 to 10 months of chronicity, 50\% with 3 to 6 months of chronicity and another $20 \%$ with 1 to 3 months of chronicity. $70 \%$ with treatment history of NSAIDs and 30\% with no treatment history. $70 \%$ with mandagni \& $30 \%$ with vishamagni. $75 \%$ with krura koshta $10 \%$ with mrudu koshta \& $15 \%$ with madhyama koshta. $70 \%$ had heel tenderness, $50 \%$ had stiffness, $50 \%$ had local swelling \& $65 \%$ had spur. In $75 \%$ it was bilateral and in $25 \%$ unilateral heel involvement was seen. 


\begin{tabular}{|l|l|l|l|l|l|l|}
\hline & 0.85 & 0.00 & & & & \\
\hline stiffness & $1.75+/-$ & $0.25+/-$ & 0.188 & 1.50 & 7.9582 & $<0.0001$ \\
& 0.72 & 0.44 & & & & \\
\hline tenderness & $2.10+/-$ & $0.35+/-$ & 0.194 & 1.75 & 9.0054 & $<0.0001$ \\
& 0.72 & 0.49 & & & & \\
\hline
\end{tabular}

The objective and subjective criteria when assessed before and after 15 days of treatment showed improvement which was statistically highly significant with $\mathrm{P}$ value $<0.001$ for all the symptoms. Complete relief from pain, tenderness, swelling was observed in 14 patients and moderate improvement in 4 patients and mild improvement in 2 patients. So this combination of eranda taila nityavirechana and kolakulathadi sthanika upanaha can be effectively adopted in patients of vatakantaka.

Table 4: showing the overall result

\begin{tabular}{|l|l|l|}
\hline Results & $\begin{array}{l}\text { No. of } \\
\text { patients }\end{array}$ & $\begin{array}{l}\text { In } \\
\text { percentage }\end{array}$ \\
\hline $\begin{array}{l}\text { Major } \\
\text { improvement }\end{array}$ & 14 & $70 \%$ \\
\hline $\begin{array}{l}\text { Moderate } \\
\text { improvement }\end{array}$ & 4 & $20 \%$ \\
\hline $\begin{array}{l}\text { Minor } \\
\text { improvement }\end{array}$ & 2 & $10 \%$ \\
\hline $\begin{array}{l}\text { No } \\
\text { improvement }\end{array}$ & 0 & $0 \%$ \\
\hline
\end{tabular}

\section{Discussion:}

Clinical presentation of patients of vatakantaka reveals that it is a saamaja vata vyadhi because peak of pain is observed in the early morning. Ruksha ushna upanaha with kolakulatthadi churna is preferred here because its ingredients are vedana sthapana, shothahara, vatakaphahara \& amahara. So, this proved very effective in relieving local pain \& swelling. As per the observations krura koshta needs anulomana of apana vata and oral administration of eranda taila is considered to be the line of treatment of vatakantaka. As this vatavyadhi is associated with aama, shunti kashaya is selected as anupana for eranda taila.
Maximum of 1 month administration of eranda taila is permitted in classics in the treatment of other vatavyadhis(13). So, it was administered for 15 days as per the koshta expecting not more than 3 to 4 virechana vegas. As this combination of treatment target towards samprapti vighatana, it proved to be very effective in vatakantaka.

\section{References:}

1. Sushruta, Sushruta samhita, with nibandha sangraha \& nyayachandrika commentary, edited by yadavji trikamji acharya, chaukamba surbharati prakashan nidana sthana, 1/79, 2008, pp269.

2. Vagbhata, Ashtanga hridaya with Sarvanga sundara \& ayurveda rasayana commentary, edited by Pdt. harisadashiva shastri paradakara,Varanasi, chaukamba Sanskrit samsthana, , nidana sthana 15/53 pp 535.

3. Agnivesha,charaka samhita, with ayurveda dipika commentary,edited by vaidya yadavji trikamji acharya,Varanasi, chaukambha sanakrit sansthan chikitsa sthana, 15/60,1994, pp 5184.

4. Harrison's principles of internal medicine, volume 2, 18th edition chapter 337, pp 2862.

5. Harrison's Principles of internal medicine, Volume 2, 18th edition chapter 337, pp 2863.

6. Govinda Das. Bhaishajya ratnavali, 16th ed. Varanasi, Chaukhambha Sanskrit samsthna; 26/48, 2002, pp 378.

7. Sushruta, Sushruta samhita, with nibandha sangraha \& nyayachandrika commentary, edited by yadavji trikamji 
acharya, chaukamba surbharati prakashan, Chikitsa sthana 4/8, 2008, pp 420.

8. Sharangdhara, sharangdhara samhita, 4th edition, Varanasi, chaukambha orientalia, pp 135.

9. Govinda Das. Bhaishajya ratnavali, 16th ed. Varanasi, Chaukhambha Sanskrit samsthna; 2002, pp 374.

10. Vagbhata, Ashtanga hridaya with Sarvanga sundara \& ayurveda rasayana commentary, edited by Pdt. Harisadashiva shastri paradakara,Varanasi, chaukamba Sanskrit samsthana, chikitsasthana 21/ 28-29, pp 724.

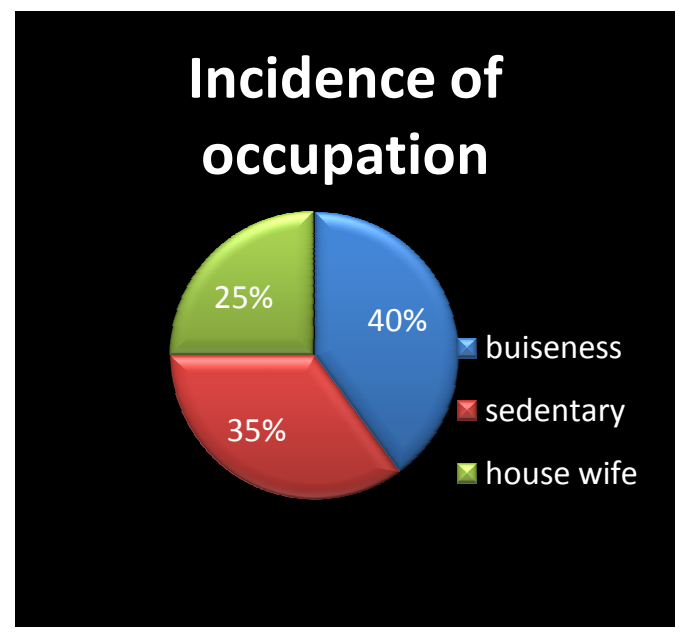

\section{Treatment} History

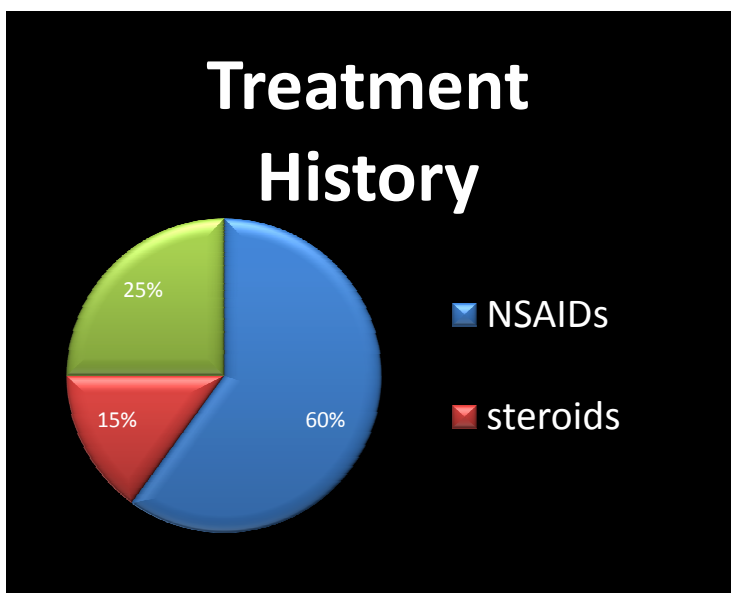

11. Agnivesha,charaka samhita, with ayurveda dipika commentary,edited by vaidya yadavji trikamji acharya,Varanasi, chaukambha sanakrit sansthan, sutrashana sthana, 14/38,1994, pp 89.

12. Agnivesha,charaka samhita, with ayurveda dipika commentary,edited by vaidya yadavji trikamji acharya,Varanasi, chaukambha sanakrit sansthan, sutrashana sthana, 14/35,1994, pp 89.

13. Chakradatta, edited by Priyavrat Sharma, Varanasi, Chaukambha publishers, 22/66, pp 191.
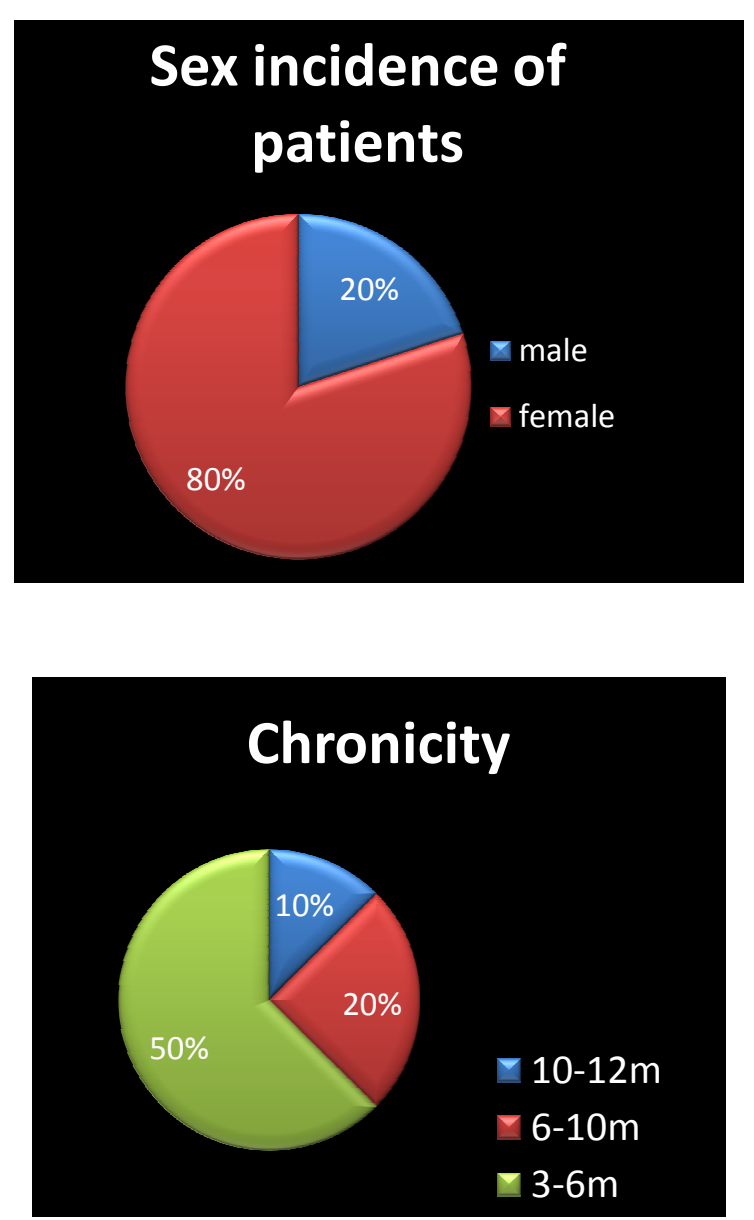

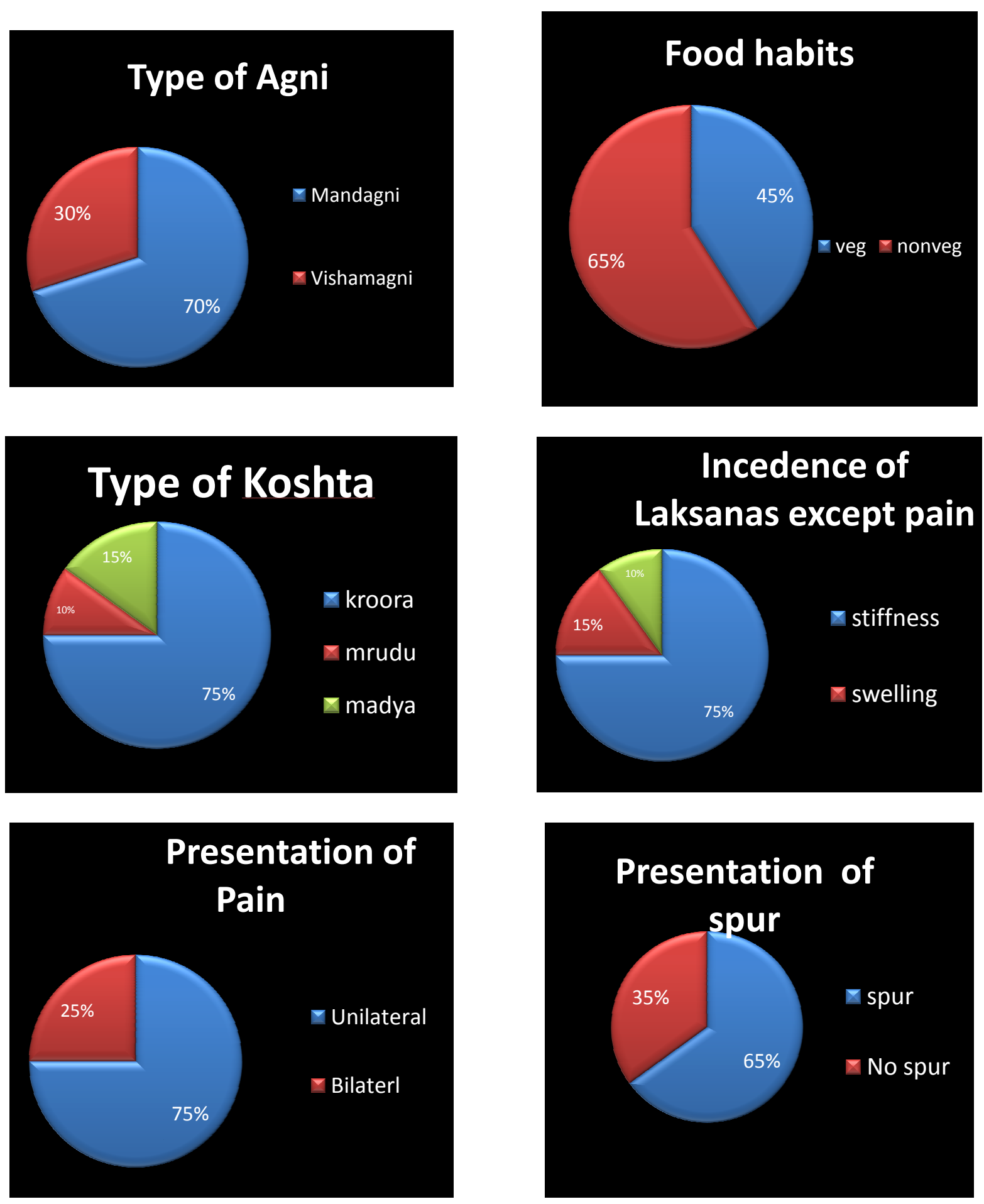

\section{Presentation of}

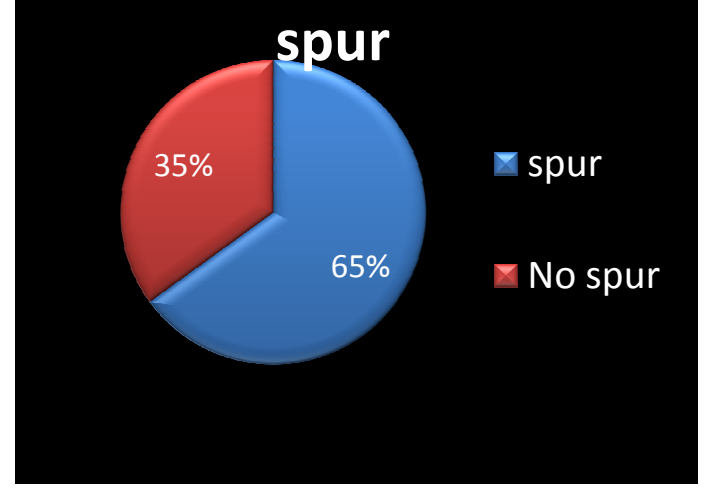

